\title{
Genetic Loci Conditioning Adult Plant Resistance to the Ug99 Race Group and Seedling Resistance to Races TRTTF and TTTTF of the Stem Rust Pathogen in Wheat Landrace Cltr 15026
}

\author{
E. M. Babiker, T. C. Gordon, and J. M. Bonman, United States Department of Agriculture-Agricultural Research Service (USDA-ARS), \\ Small Grains and Potato Germplasm Research Unit, Aberdeen, ID 83210; S. Chao, USDA-ARS, Cereal Crops Research, Fargo, ND 58102; \\ M. N. Rouse and Y. Jin, USDA-ARS, Cereal Disease Laboratory, St. Paul, MN 55108; M. Newcomb, School of Plant Sciences, University of \\ Arizona, Maricopa; R. Wanyera, Kenya Agricultural and Livestock Research Organization, Njoro 20107, Kenya; and S. Bhavani, Interna- \\ tional Maize and Wheat Improvement Center, Nairobi, Kenya
}

\begin{abstract}
Wheat landrace CItr 15026 previously showed adult plant resistance (APR) to the Ug99 stem rust race group in Kenya and seedling resistance to Puccinia graminis f. sp. tritici races QFCSC, TTTTF, and TRTTF. CItr 15026 was crossed to susceptible accessions LMPG-6 and Red Bobs, and 180 double haploid (DH) lines and 140 recombinant inbred lines (RIL), respectively, were developed. The $90 \mathrm{~K}$ wheat iSelect singlenucleotide polymorphism platform was used to genotype the parents and populations. Parents and $180 \mathrm{DH}$ lines were evaluated in the field in Kenya for three seasons. A major quantitative trait locus (QTL) for APR was consistently detected on chromosome arm 6AS. This QTL was further detected

in the RIL population screened in Kenya for one season. Parents, $F_{1}$, and the two populations were tested as seedlings against races TRTTF and TTTTF. In addition, the DH population was tested against race QFCSC. Goodness-of-fit tests indicated that the TRTTF resistance in CItr 15026 was controlled by two complementary genes whereas the TTTTF and QFCSC resistance was conditioned by one dominant gene. The TRTTF resistance loci mapped to chromosome arms 6AS and 6DS, whereas the TTTTF and QFCSC resistance locus mapped to the same region on 6DS as the TRTTF resistance. The APR identified in CItr 15026 should be useful in developing cultivars with durable stem rust resistance.
\end{abstract}

The Ug99 race group of Puccinia graminis f. sp. tritici Eriks. \& E. Henn. has overcome the stem rust resistance genes $\operatorname{Sr} 31, \mathrm{Sr} 24$, Sr36, and SrTmp, which were deployed in many wheat cultivars worldwide (Jin and Singh 2006; Jin et al. 2008, 2009; Newcomb et al. 2016; Olivera et al. 2015). The use of resistant cultivars is the most effective and low-cost means to control wheat stem rust (Roelfs and Bushnell 1985). The widespread deployment of single racespecific resistance genes often results in the evolution of new virulent races of the pathogen, such as members of the $\mathrm{Ug} 99$ race group, and can result in stem rust epidemics. Consequently, it is necessary to find novel sources of resistance and to deploy these genes together with other effective genes to enhance their longevity (Singh et al. 2008, 2011a). In contrast to race-specific resistance conferred by major genes, adult plant resistance (APR) is expressed in the later stages of plant development and is thought to have more complex inheritance (Singh et al. 2011b). APR is also often incomplete in that the pathogen can reproduce, although reproduction is much less than a fully susceptible response (Singh et al. 2011a). APR to stem rust is likely to be more durable because the best-characterized gene for stem rust APR, $S r 2$, has maintained its effectiveness for more than 60 years (Singh et al. 2011a,b). In addition to $S r 2$, four other resistance genes have been identified and classified as APR genes for stem rust in wheat (Lr67/Yr46/Sr55/Pm46, Sr56, Lr34/Yr18/ Sr57/Pm38, and Lr46/Yr29/ Sr58/Pm39) (Bansal et al. 2014; Herrera-Foessel et al. 2014; Lagudah et al. 2009; McFadden 1930; Singh et al. 2011b). Discovering new APR genes and identifying markers linked to the genes is important for control of the Ug99 race group, given the continued evolution of the pathogen toward greater virulence to specific major genes.

In previous efforts, 2,509 wheat landraces from the National Small Grains Collection (NSGC) were evaluated for field resistance to the

Corresponding author: J. M. Bonman; E-mail: Mike.Bonman@ars.usda.gov Accepted for publication 1 November 2016.

This article is in the public domain and not copyrightable. It may be freely reprinted with customary crediting of the source. The American Phytopathological Society, 2017.
Ug99 race group in stem rust nurseries in Kenya. Among these accessions, wheat landrace CItr 15026, originally collected in Afghanistan, consistently displayed severities and infection responses ranging from 15 moderately resistant-resistant (MRR) to 25 moderately resistant (MR) (Newcomb et al. 2013). However, when tested at the seedling stage, CItr 15026 exhibited high infection type (IT) 3 to $P$. graminis f. sp. tritici races TTKSK and TTKST, indicating that this accession has APR to the Ug99 race group. In addition, when inoculated at the seedling stage with $P$. graminis f. sp. tritici races TRTTF and TTTTF, which are distinct from the Ug99 race group (Olivera et al. 2015), CItr 15026 exhibited low IT of ';1' and '2,' respectively. Race TRTTF is a highly virulent race with virulence to $\mathrm{Sr} 9 e, \mathrm{Srl3}$, and $\operatorname{Sr} 1 R S^{\text {Amigo }}$ genes that are important in durum and winter wheat cultivars in the United States (Olivera et al. 2012). Because APR is usually controlled by a combination of genes, molecular markers associated with APR will be useful for selecting the APR in CItr 15026 in the presence of race-specific resistance in breeding populations. The objectives of this study were to map the seedling stage resistance and APR in CItr 15026 and identify single-nucleotide polymorphism (SNP) markers that could be used in marker-assisted selection.

\section{Materials and Methods}

Population development. To elucidate genetic control of stem rust resistance in CItr 15026, two populations were generated: 180 double haploids $(\mathrm{DH})$ from a cross with LMPG-6 and $140\left(\mathrm{~F}_{2: 6}\right)$ recombinant inbred lines (RIL) derived from a single $\mathrm{F}_{1}$ seed from a cross with Red Bobs. CItr15026 is a hexaploid wheat (Triticum aestivum subsp. aestivum) landrace from the NSGC that was collected from Afghanistan in 1968. LMPG-6 (Knott 1990) and Red Bobs (Dyck and Green 1970) are highly susceptible wheat lines. Initial results showed that seedling resistance to $P$. graminis $\mathrm{f}$. sp. tritici races TRTTF and TTTTF mapped to the short arm of chromosomes 6A and 6D; therefore, five wheat accessions carrying $\mathrm{Sr} 8 a$ (ISr8a-Ra) and $\mathrm{Sr} 8 b$ (CItr 14196) on chromosome 6AS and Sr5 (ISr5-Ra), SrCad (AC Cadillac), and $\mathrm{Sr} 42$ (Norin 40) on chromosome 6DS were included in this study.

Seedling screening. Parents, ISr8a-Ra, CItr 14196, ISr5-Ra, AC Cadillac, Norin $40, \mathrm{~F}_{1}$ seedlings, and the two populations were screened with $P$. graminis f. sp. tritici races TRTTF (isolate 06YEM34-1) and TTTTF (isolate 01MN84A-1-2) at the United States Department of 
Agriculture-Agricultural Research Service (USDA-ARS) Cereal Disease Laboratory in St. Paul, MN following the protocol described by Rouse et al. (2011). Parents and $180 \mathrm{DH}$ lines were tested against $P$. graminis f. sp. tritici race QFCSC (isolate 06ND76C) in Aberdeen, ID. About five seedlings from each line were tested and seedling IT were recorded using the 0-to-4 scale developed by Stakman et al. (1962). To test for goodness-of-fit to the models of one, two, or four genes, $\chi^{2}$ analyses were performed.

Field screening. Parents and 180 DH lines from the LMPG-6/CItr 15026 cross were evaluated for field resistance to the Ug99 race group at the adult plant stage in stem rust nurseries in Njoro, Kenya during three growing seasons in May 2013, May 2014, and October 2014. To validate the $\mathrm{DH}$ mapping results, parents, $\mathrm{F}_{1}$, and 140 RIL from the Red Bobs/CItr 15026 cross were evaluated for field resistance in Kenya during one growing season in October 2015. The entries were planted in 1-m rows with two replicates and with six replicates for each of the parents and Red Bobs. A mixture of cultivars with Sr31 (susceptible to TTKSK) and $\mathrm{Sr} 24$ (susceptible to TTKST) were planted adjacent to the plots as spreader rows. The spreader rows were inoculated with a bulk collection of $P$. graminis $\mathrm{f}$. sp. tritici isolates of the $\mathrm{Ug} 99$ race group at the jointing growth stage to produce spores for natural dispersal to the experimental plots. The modified Cobb scale (Peterson et al. 1948) was used to assess the stem rust severity (0 to 100\%) at the soft dough stage and the infection response was rated as susceptible (S), moderately susceptible (MS), moderate susceptible-susceptible (MSS), moderate (M), MR, and resistant (R) (Roelfs et al. 1992). For each line, the stem rust severity was multiplied by a constant value for infection response to obtain the coefficient of infection (CI), as described by Knott (1989).

Map construction and quantitative trait loci analysis. Total genomic DNA was extracted from leaves of 2-week-old seedlings using the cetyltrimethylammonium bromide protocol, with modification (Babiker et al. 2015). The 90K iSelect SNP genotyping platform was used to genotype parents, $180 \mathrm{DH}$ lines, $140 \mathrm{RIL}$, and $\mathrm{F}_{1}$ seedlings from the Red Bobs/CItr 15026 cross, as described by the manufacturer (Illumina). Allele calling for each SNP was performed using Illumina's GenomeStudio v2011.1, and manually inspected for call accuracy. SNP markers polymorphic between parents with less than $9 \%$ missing data were selected and used to construct the genetic linkage maps using JMP Genomics 7.1 (SAS Institute). The recombination and linkage groups function with a minimal genetic distance of 30 centimorgans (cM) was used to determine the initial number of linkage groups. The linkage map order function was used to determine the most likely marker order. The single-marker analysis (SMA) function was used to identify markers with significant effects, while the composite interval mapping (CIM) analysis function was used to generate a composite interval map of quantitative trait loci (QTL) with a minimum logarithm of odds threshold of 3.0. Genetic distances between markers were calculated in centimorgans using the Kosambi map function and linkage groups were assigned to chromosomes based on the $90 \mathrm{~K}$ consensus map (Wang et al. 2014).

\section{Results}

Inheritance of seedling resistance to $P$. graminis $\mathbf{f}$. $\mathbf{s p}$. tritici races QFCSC and TTTTF. When tested at the seedling stage against $P$. graminis f. sp. tritici races QFCSC and TTTTF, CItr 15026 showed a low IT score of ' 2 ' whereas LMPG-6 and Red Bobs exhibited S reactions. with IT of ' $3+$ ' and '4.' The DH population segregated in a 1:1 ratio for each race, with $\chi^{2}=0.46, P=0.49(\mathrm{R}: \mathrm{S}=91: 82)$ for QFCSC and $\chi^{2}=0.36, P=0.55$ (R:S = 94:86) for TTTTF. The $\mathrm{F}_{1}$ seedlings exhibited IT of ' 2 ' to races QFCSC and TTTTF, indicating that resistance to races QFCSC and TTTTF is controlled by a single dominant gene.

The segregation ratio in the RIL population fitted the 1:1 expectation for a single gene $\left(\chi^{2}=0.074, P=0.78\right)$ for race TTTTF $(\mathrm{R}: \mathrm{S}=$ 59:62). RIL resistant to race TTTTF exhibited IT of '2-' and ' 2 ' and susceptible RIL exhibited IT of ' $3+$ ' and ' 4 .' When tested against race TTTTF, ISr8a-Ra, CItr 14196, ISr5-Ra, AC Cadillac, and Norin 40 displayed high IT of ' $3+$ ' and '4,' indicating that CItr 15026 most likely has a novel resistance gene or allele effective to race TTTTF. The TTTTF resistance gene or allele was temporally designated Sr15026.

Inheritance of seedling resistance to $P$. graminis $\mathbf{f}$. sp. tritici race TRTTF. When tested against race TRTTF at the seedling stage, CItr 15026 displayed IT of ; ' 1 ' whereas LMPG- 6 , Red Bobs, and $F_{1}$ seedlings exhibited a completely susceptible reaction, with IT of ' $3+$ ' and ' 4 ' indicating recessive resistance. RIL resistant to race TRTTF exhibited IT of '2-' and '2' and susceptible RIL exhibited IT of ' $3+$ ' and '4.' The DH and the RIL populations segregated in a 3:1 (S:R) ratio $\left(\chi^{2}=0.0922, P=0.79\right.$ and $\chi^{2}=0.298, P=0.58$, respectively), indicating that CItr 15026 had two complimentary genes for resistance to race TRTTF and at least one of the genes is recessive. Among the DH population, 131 lines were susceptible and 46 were resistant to race TRTTF. The monogenic line ISr8a-Ra exhibited an IT score of ' 2 ' to race TRTTF, whereas CItr 14196, ISr5Ra, AC Cadillac, and Norin 40 displayed IT scores of ' $3+$ ' and '4,' indicating that CItr 15026 most likely has a novel resistance gene effective to race TRTTF.

Mapping seedling resistance to $P$. graminis f. sp. tritici races QFCSC, TRTTF, and TTTTF. In the DH population, 6,202 SNP markers previously assigned to chromosomes (Wang et al. 2014) were anchored to 41 linkage groups representing all 21 wheat chromosomes, with a total map length of $2,812 \mathrm{cM}$. SMA revealed the presence of one locus for resistance to QFCSC and TTTTF on the short arm of chromosome 6D. Eight SNP markers were
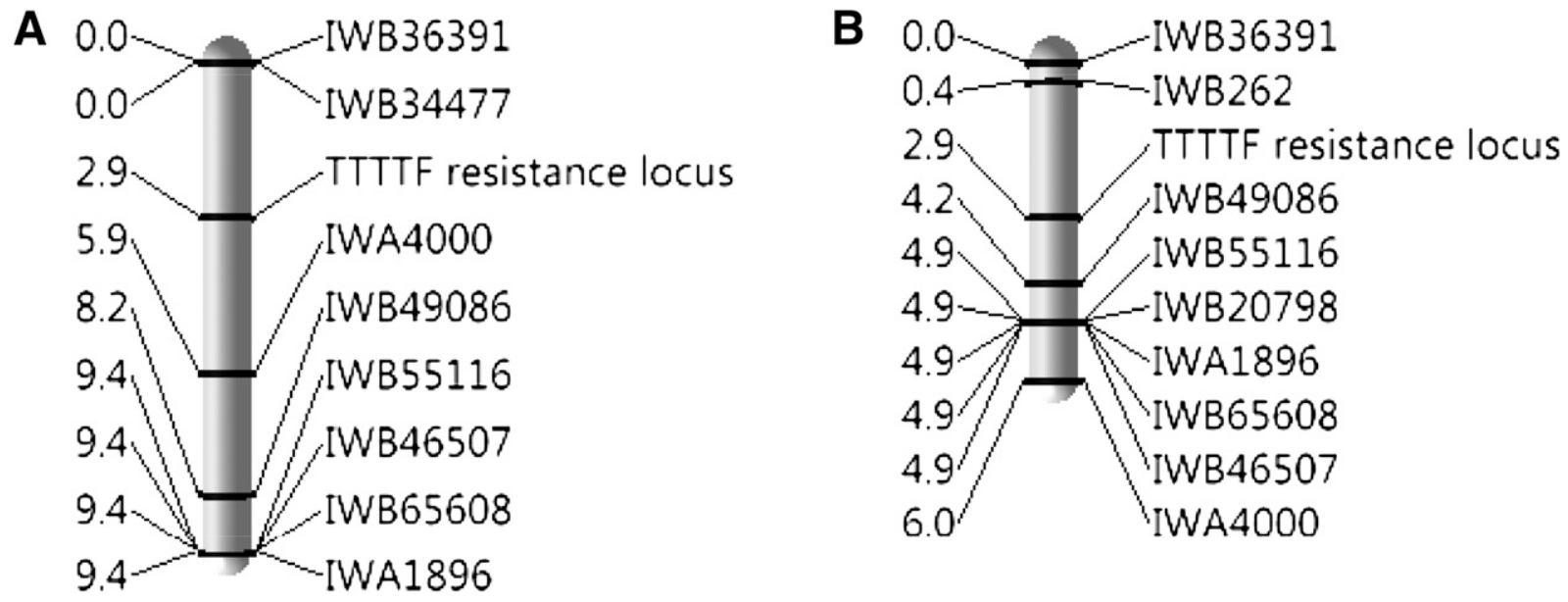

Fig. 1. Single-nucleotide polymorphism-based genetic linkage maps of the Srgene in Cltr 15026 on chromosome 6DS for resistance to races QFCSC and TTTTF constructed from the A, LMPG-6/Cltr 15026 double haploid population and B, Red Bobs/Cltr 15026 recombinant inbred line population. Values next to the marker names are the distances (in centimorgans) generated using the Kosambi mapping function. 
associated with the QFCSC and TTTTF resistance locus on chromosome 6DS. The SNP markers IWB34477 and IWB36391 were mapped $2.9 \mathrm{cM}$ distal to the QFCSC and TTTTF resistance locus, whereas the SNP marker IWA4000 was mapped $2.93 \mathrm{cM}$ proximal to the resistance locus (Fig. 1A). Two loci for resistance to race TRTTF were mapped to the short arm of chromosomes 6A and 6D. The same eight SNP markers associated with resistance to races QFCSC and TTTTF were associated with the TRTTF resistance on 6DS. In addition to the 6DS markers, a group of $22 \mathrm{SNP}$ markers mapped $19.5 \mathrm{cM}$ distal to the TRTTF resistance locus on chromosome 6AS (Fig. 2A).
A

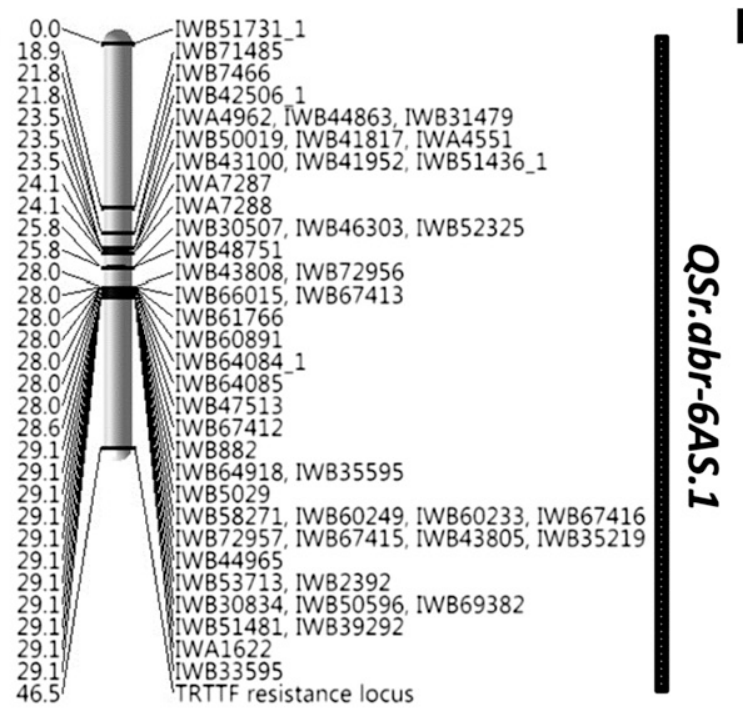

B

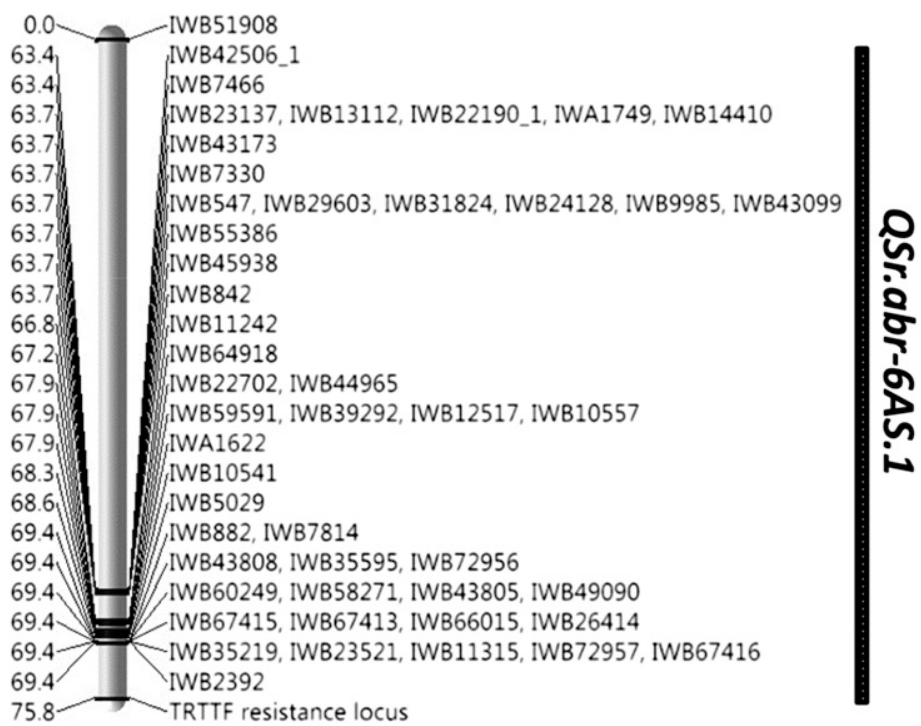

Fig. 2. Single-nucleotide polymorphism-based genetic linkage maps of the adult plant resistance locus in Cltr 15026 on chromosome 6 AS constructed from the A, LMPG-6/Cltr 15026 double haploid population and B, Red Bobs/Cltr 15026 recombinant inbred line population using an iSelect 90K Infinium assay. Values next to the marker names are the distances (in centimorgans) generated using the Kosambi mapping function.

Table 1. Quantitative trait loci for adult plant resistance to Ug99 in the LMPG-6/CItr 15026 double haploid population assessed in three seasons in Kenya ${ }^{\mathrm{a}}$

\begin{tabular}{|c|c|c|c|c|c|c|c|c|c|c|c|}
\hline \multirow[b]{2}{*}{ SNP ID } & \multirow[b]{2}{*}{ Chr } & \multirow[b]{2}{*}{ Pos (cM) } & \multicolumn{3}{|c|}{ May-2103 } & \multicolumn{3}{|c|}{ May-2104 } & \multicolumn{3}{|c|}{ October-2104 } \\
\hline & & & LOD & $\mathbf{A E}$ & $R^{2}(\%)$ & LOD & $\mathbf{A E}$ & $R^{2}(\%)$ & LOD & $\mathbf{A E}$ & $R^{2}(\%)$ \\
\hline IWB51731_1 & $6 \mathrm{AS}$ & 40.60 & 2.08 & -8.4 & 10.3 & 3.1 & -10.0 & 9.5 & 4.6 & -18.3 & 21.2 \\
\hline IWB71485 & $6 \mathrm{AS}$ & 35.71 & 3.19 & -10.2 & 10.8 & 7.1 & -14.6 & 20.3 & 6.4 & -20.7 & 28.5 \\
\hline IWB7466 & $6 \mathrm{AS}$ & 28.85 & 3.36 & -10.4 & 10.8 & 7.5 & -14.8 & 21.3 & 6.7 & -20.9 & 29.7 \\
\hline IWB42506_1 & $6 \mathrm{AS}$ & 30.15 & 3.36 & -10.4 & 10.5 & 7.5 & -14.8 & 21.3 & 6.7 & -20.9 & 29.7 \\
\hline IWA4962, IWB44863, IWB31479 & $6 \mathrm{AS}$ & 21.12 & 3.25 & -10.3 & 10.5 & 7.6 & -14.9 & 21.5 & 6.9 & -21.2 & 30.1 \\
\hline IWB50019, IWB41817, IWA4551 & $6 \mathrm{AS}$ & 22.91 & 3.25 & -10.3 & 10.5 & 7.6 & -14.9 & 21.5 & 6.9 & -21.2 & 30.1 \\
\hline IWB43100, IWB41952, IWB51436_1 & 6AS & 27.15 & 3.25 & -10.3 & 9.3 & 7.6 & -14.9 & 21.5 & 6.9 & -21.2 & 30.1 \\
\hline IWA7287 & $6 \mathrm{AS}$ & 27.15 & 2.87 & -9.7 & 9.3 & 6.8 & -14.3 & 19.5 & 6.2 & -20.4 & 27.6 \\
\hline IWA7288 & $6 \mathrm{AS}$ & 24.30 & 2.87 & -9.7 & 11.0 & 6.8 & -14.3 & 19.5 & 6.2 & -20.4 & 27.6 \\
\hline IWB30507, IWB46303, IWB52325 & $6 \mathrm{AS}$ & 25.53 & 3.41 & -10.5 & 10.8 & 8.7 & -15.9 & 24.2 & 6.9 & -21.2 & 30.1 \\
\hline IWB48751 & $6 \mathrm{AS}$ & 21.12 & 3.34 & -10.5 & 10.7 & 8.8 & -16.1 & 24.6 & 7.1 & -21.6 & 31.1 \\
\hline IWB43808, IWB72956 & $6 \mathrm{AS}$ & 16.58 & 3.33 & -10.5 & 10.7 & 8.8 & -16.1 & 24.6 & 7.1 & -21.6 & 31.1 \\
\hline IWB66015, IWB67413 & $6 \mathrm{AS}$ & 13.45 & 3.33 & -10.5 & 10.7 & 8.8 & -16.1 & 24.6 & 7.1 & -21.6 & 31.1 \\
\hline IWB61766 & $6 \mathrm{AS}$ & 12.91 & 3.33 & -10.5 & 10.7 & 8.8 & -16.1 & 24.6 & 7.1 & -21.6 & 31.1 \\
\hline IWB60891 & $6 \mathrm{AS}$ & 6.98 & 3.33 & -10.5 & 10.7 & 8.8 & -16.1 & 24.6 & 7.1 & -21.6 & 31.1 \\
\hline IWB64084_1 & $6 \mathrm{AS}$ & 4.73 & 3.33 & -10.5 & 10.7 & 8.8 & -16.1 & 24.6 & 7.1 & -21.6 & 31.1 \\
\hline IWB64085 & $6 \mathrm{AS}$ & 3.86 & 3.33 & -10.5 & 10.7 & 8.8 & -16.1 & 24.6 & 7.1 & -21.6 & 31.1 \\
\hline IWB47513 & $6 \mathrm{AS}$ & 3.79 & 3.33 & -10.5 & 10.7 & 8.8 & -16.1 & 24.6 & 7.1 & -21.6 & 31.1 \\
\hline IWB67412 & $6 \mathrm{AS}$ & 13.45 & 3.33 & -10.5 & 10.7 & 8.8 & -16.1 & 24.6 & 7.1 & -21.6 & 31.1 \\
\hline IWB882 & $6 \mathrm{AS}$ & 16.96 & 3.33 & -10.5 & 10.7 & 8.8 & -16.1 & 24.6 & 7.1 & -21.6 & 31.1 \\
\hline IWB64918, IWB35595 & $6 \mathrm{AS}$ & 16.58 & 3.33 & -10.5 & 10.7 & 8.8 & -16.1 & 24.6 & 7.1 & -21.6 & 31.1 \\
\hline IWB5029 & $6 \mathrm{AS}$ & 16.00 & 3.33 & -10.5 & 10.7 & 8.8 & -16.1 & 24.6 & 7.1 & -21.6 & 31.1 \\
\hline $\begin{array}{l}\text { IWB58271, IWB60249, IWB60233, } \\
\text { IWB67416 }\end{array}$ & $6 \mathrm{AS}$ & 13.45 & 3.33 & -10.5 & 10.7 & 8.8 & -16.1 & 24.6 & 7.1 & -21.6 & 31.1 \\
\hline $\begin{array}{l}\text { IWB72957, IWB67415, IWB43805, } \\
\text { IWB35219 }\end{array}$ & $6 \mathrm{AS}$ & 13.45 & 3.33 & -10.5 & 10.7 & 8.8 & -16.1 & 24.6 & 7.1 & -21.6 & 31.1 \\
\hline IWB44965 & $6 \mathrm{AS}$ & 12.91 & 3.33 & -10.5 & 10.7 & 8.8 & -16.1 & 24.6 & 7.1 & -21.6 & 31.1 \\
\hline IWB53713, IWB2392 & $6 \mathrm{AS}$ & 12.48 & 3.33 & -10.5 & 10.7 & 8.8 & -16.1 & 24.6 & 7.1 & -21.6 & 31.1 \\
\hline IWB30834, IWB50596, IWB69382 & $6 \mathrm{AS}$ & 6.98 & 3.33 & -10.5 & 10.7 & 8.8 & -16.1 & 24.6 & 7.1 & -21.6 & 31.1 \\
\hline IWB51481, IWB39292 & $6 \mathrm{AS}$ & 6.43 & 3.33 & -10.5 & 10.7 & 8.8 & -16.1 & 24.6 & 7.1 & -21.6 & 31.1 \\
\hline IWA1622 & $6 \mathrm{AS}$ & 4.73 & 3.33 & -10.5 & 10.7 & 8.8 & -16.1 & 24.6 & 7.1 & -21.6 & 31.1 \\
\hline IWB33595 & $6 \mathrm{AS}$ & 3.43 & 3.33 & -10.5 & 10.7 & 8.8 & -16.1 & 24.6 & 7.1 & -21.6 & 31.1 \\
\hline
\end{tabular}

${ }^{\mathrm{a}} \mathrm{Chr}=$ chromosome, $\mathrm{Pos}=$ distance based on a reference consensus map (Wang et al. 2014), LOD = logarithm of odds, and AE $=$ additive effect. 
To verify mapping results from the DH population in the RIL population, 3,817 SNP markers were polymorphic between Red Bobs and CItr 15026 and detected as heterozygous in $F_{1}$ seedlings. These SNP markers were anchored to 28 linkage groups representing all 21 wheat chromosomes, with a total map length of $1,543.7 \mathrm{cM}$. Using SMA, the TTTTF resistance locus was mapped to the short arm of chromosome 6D and was flanked by nine SNP markers. Of the nine, seven SNP markers were detected on the DH population. Relative to the TTTTF locus, IWB262 was mapped $2.5 \mathrm{cM}$ proximal and IWB49086 was mapped $1.3 \mathrm{cM}$ distal (Fig. 1B). Using the SMA function, two regions for resistance to TRTTF were detected on the short arms of chromosomes 6D and 6A. The TRTTF resistance locus on 6DS mapped to the same location as the TTTTF resistance. On chromosome 6AS, a group of 19 SNP markers mapped $15.9 \mathrm{cM}$ distal from TRTTF resistance locus on 6AS (Fig. 2B).

Mapping adult plant field resistance. Parents and $\mathrm{DH}$ lines from LMPG-6/CItr 15026 were tested for three seasons in the field stem rust nursery in Njoro, Kenya in 2013 and 2014. The resistant parent, CItr 15026, displayed disease severities and infection responses ranging from $10 \mathrm{MRR}$ to $20 \mathrm{M}$, whereas LMPG-6 exhibited responses ranging from $45 \mathrm{MSS}$ to $60 \mathrm{~S}$. The severities and infection responses of the DH population ranged from $10 \mathrm{MRR}$ to $60 \mathrm{~S}$. In the DH population, QTL analyses were conducted for each season using the mean CI values calculated from replicates. Using the CIM function, one QTL for resistance to $\mathrm{Ug} 99$ was detected on the short arm of chromosome $6 \mathrm{~A}$ at a $10.2-\mathrm{cM}$ interval (Table 1; Fig. 2A). This QTL was consistently detected across the three seasons and explained 10 to $31 \%$ of the phenotypic variation. The detected QTL was designated as QSr.abr-6AS.1 (Fig. 2A).

To validate the QTL detected in the DH population, parents, RIL, and $F_{1}$ from the Red Bobs/CItr 15026 cross were evaluated for field resistance to Ug99 in Njoro, Kenya during the main growing season in 2015. CItr 15026 displayed disease severities and infection responses ranging from $10 \mathrm{MRR}$ to $20 \mathrm{M}$ and Red Bobs exhibited responses ranging from $45 \mathrm{MSS}$ to $60 \mathrm{~S}$. The $\mathrm{F}_{1}$ seedlings displayed a disease severity and infection response of $60 \mathrm{~S}$ in two replicates, indicating that the APR is conditioned by recessive genes in CItr
15026. The severities and infection responses of the RIL ranged from $10 \mathrm{MRR}$ to $80 \mathrm{~S}$. QTL analysis was conducted using the average CI values from the two replicates. One QTL for APR was detected on chromosome arm 6AS at a 6.01-cM interval and it explained 10 to $19 \%$ of the phenotypic variation (Table 2 ; Fig. 2B). Of the 43 significant markers detected in the DH population, $15 \mathrm{SNP}$ were found to be significant in the RIL population.

\section{Discussion}

Wheat landrace CItr 15026 consistently showed a high level of APR to the Ug99 race group in the stem rust nursery in Kenya over many years (Newcomb et al. 2013). CItr 15026 was negative for the presence of molecular markers for Rht-B1d, Rht-D1b, Sr2, Sr22, Sr24, Sr26, Sr31, Sr36, Lr34, and Lr19/Sr25, indicating that CItr 15026 is most likely a landrace and not a product of modern breeding (Newcomb et al. 2013). When tested against $P$. graminis f. sp. tritici races TTKSK and TTKST at the seedling stage, CItr 15026 showed susceptible ITs to the two races, indicating that CItr 15026 has APR to the Ug99 race group. In two different stripe rust nurseries in Washington state, CItr 15026 was found to possess field resistance to several races of $P$. striiformis f. sp. tritici (Sthapit et al. 2014). In addition, when tested against $P$. graminis f. sp. tritici races TRTTF, TTTTF, and QFCSC, it displayed low IT to the three races. Based on the $\chi^{2}$ analyses results, the TRTTF resistance in CItr 15026 was found to be governed by two complimentary recessive genes. Singh and McIntosh (1987) found that the APR in 'Chris' wheat is controlled by two complementary genes. In addition to $\operatorname{Sr} 7 a$ and $\operatorname{Sr} 12$, Chris possessed $\mathrm{Sr} 5$ and $\mathrm{Sr} 8 \mathrm{a}$ on chromosome arms 6DS and 6AS, respectively. When tested against race TRTTF, none of the progeny from the two crosses displayed IT similar to CItr 15026. In addition, not all progeny with TTTTF resistance were resistant to race TRTTF, indicating a complex interaction between different loci. The loci for seedling resistance to race TRTTF were mapped to chromosome arms 6AS and 6DS using two mapping populations. To date, one TRTTF-effective $\mathrm{Sr}$ gene, $\operatorname{Sr} 8 a$, has been described on chromosome arm 6AS. $S r 8 a$ is effective against $P$. graminis f. sp. tritici race TRTTF with IT of ' 2 '

Table 2. Quantitative trait loci for adult plant resistance to Ug99 in the Red Bobs/CItr 15026 recombinant inbred line population assessed in one season in Kenya ${ }^{\mathrm{a}}$

\begin{tabular}{|c|c|c|c|c|c|}
\hline \multirow[b]{2}{*}{ SNP ID } & \multirow[b]{2}{*}{ Chr } & \multirow[b]{2}{*}{ Pos (cM) } & \multicolumn{3}{|c|}{ October 2015} \\
\hline & & & LOD & $\mathbf{A E}$ & $R^{2}(\%)$ \\
\hline IWB42506_1 & 6AS & 30.15 & 3.11 & -12.28 & 10 \\
\hline IWB7466 & $6 \mathrm{AS}$ & 28.85 & 3.11 & -12.28 & 10 \\
\hline $\begin{array}{l}\text { IWB23137, IWB13112, IWB22190_1, } \\
\text { IWA1749, IWB14410 }\end{array}$ & $6 \mathrm{AS}$ & 27.15 & 3.57 & -13.19 & 12 \\
\hline IWB43173 & 6AS & 25.86 & 3.57 & -13.19 & 12 \\
\hline IWB7330 & $6 \mathrm{AS}$ & 25.55 & 3.57 & -13.19 & 12 \\
\hline $\begin{array}{l}\text { IWB547, IWB29603, IWB31824, } \\
\text { IWB24128, IWB9985, IWB43099 }\end{array}$ & $6 \mathrm{AS}$ & 25.53 & 3.57 & -13.19 & 12 \\
\hline IWB55386 & $6 \mathrm{AS}$ & 23.62 & 3.57 & -13.19 & 12 \\
\hline IWB45938 & $6 \mathrm{AS}$ & 22.97 & 3.57 & -13.19 & 12 \\
\hline IWB842 & $6 \mathrm{AS}$ & 21.99 & 4.31 & -14.74 & 14 \\
\hline IWB11242 & $6 \mathrm{AS}$ & 19.24 & 4.68 & -15.20 & 15 \\
\hline IWB64918 & 6AS & 16.58 & 4.15 & -14.42 & 14 \\
\hline IWB22702, IWB44965 & 6AS & 12.91 & 5.38 & -16.23 & 17 \\
\hline $\begin{array}{l}\text { IWB59591, IWB39292, IWB12517, } \\
\text { IWB10557 }\end{array}$ & $6 \mathrm{AS}$ & 6.43 & 5.38 & -16.23 & 17 \\
\hline IWA1622 & $6 \mathrm{AS}$ & 4.73 & 5.38 & -16.23 & 17 \\
\hline IWB5029 & $6 \mathrm{AS}$ & 16.00 & 5.08 & -15.76 & 16 \\
\hline IWB10541 & $6 \mathrm{AS}$ & 3.43 & 5.98 & -17.08 & 19 \\
\hline IWB882, IWB7814 & $6 \mathrm{AS}$ & 16.96 & 3.89 & -13.92 & 13 \\
\hline IWB43808, IWB35595, IWB72956 & $6 \mathrm{AS}$ & 16.58 & 3.89 & -13.92 & 13 \\
\hline $\begin{array}{l}\text { IWB60249, IWB58271, IWB43805, } \\
\text { IWB49090 }\end{array}$ & $6 \mathrm{AS}$ & 13.45 & 3.89 & -13.92 & 13 \\
\hline $\begin{array}{l}\text { IWB67415, IWB67413, IWB66015, } \\
\text { IWB26414 }\end{array}$ & $6 \mathrm{AS}$ & 13.45 & 3.89 & -13.92 & 13 \\
\hline $\begin{array}{l}\text { IWB35219, IWB23521, IWB11315, } \\
\text { IWB72957, IWB67416 }\end{array}$ & $6 \mathrm{AS}$ & 13.45 & 3.89 & -13.92 & 13 \\
\hline IWB2392 & $6 \mathrm{AS}$ & 12.48 & 3.89 & -13.92 & 13 \\
\hline
\end{tabular}

${ }^{\mathrm{a}} \mathrm{Chr}=$ chromosome, $\mathrm{Pos}=$ distance based on a reference consensus map (Wang et al. 2014), LOD = logarithm of odds, and AE = additive effect. 
(Olivera et al. 2012). Based on the $\chi^{2}$ result, the TRTTF resistance in SD4279, a line postulated to carry $\operatorname{Sr} 8 a$, was found to be conditioned by a single dominant gene (Guerrero et al. 2015). Mapping using the 9K Illumina SNP genotyping platform located Sr8a on the distal part of chromosome arm 6AS (Guerrero et al. 2015). Using association mapping, Bajgain et al. (2015) detected 57 SNP markers to be associated with the TRTTF resistance on chromosome arm 6AS. Of these, 11 SNP markers were detected in both the DH and RIL populations used in the present study. Though the map location is not suggestive of any difference between $S r 8 a$ and the TRTTF resistance locus in CItr 15026, the dominant gene action of $S r 8 a$ and the IT displayed by Sr8a and CItr 15026 suggest that the TRTTF resistance in CItr 15026 is independent of $\mathrm{Sr} 8 a$. Further allelism studies are needed to explain any relationship between $S r 8 a$ and the TRTTF locus in CItr 15026.

The second TRTTF resistance locus was mapped to the short arm of chromosome 6D at the same location as resistance to TTTTF and QFCSC. Two of the detected SNP markers in both populations, IWB36391 and IWB49086, were previously found to be associated with $\mathrm{Sr} 42$ and $\mathrm{SrCad}$, respectively (Gao et al. 2015; Kassa et al. 2016). Based on the location of the closely linked SNP markers, we predicted the 6DS locus to be close to $\mathrm{Sr} 5, \mathrm{Sr} 42$, or $\mathrm{SrCad}$ (Ghazvini et al. 2012; Hiebert et al. 2011). It is likely that $\mathrm{SrCad}$ is an allele of Sr42 (Gao et al. 2015). However, when tested against $P$. graminis f. sp. tritici races TTTTF and QFCSC, $S r 5, S r 42$, and $S r C a d$ displayed high IT to both races. This excluded the possibility of having neither Sr5, Sr42, nor SrCad in CItr 15026. Therefore, we concluded that the resistance to $P$. graminis $\mathrm{f}$. $\mathrm{sp}$. tritici races TTTTF and QFCSC in CItr 15026 could be controlled by a novel allele or gene on $6 \mathrm{DS}$.

Within the region with the seedling resistance to race TRTTF on chromosome arm 6AS, one major QTL for APR to the Ug99 race group was consistently detected in four seasons in the field nurseries in Kenya. In the DH and RIL populations, the QTL region was flanked by 48 and 43 SNP markers, respectively. Of these, 15 SNP markers were consistently detected in both populations. In previous studies, five designated genes $(\mathrm{Sr} 2, \mathrm{Sr} 55, \mathrm{Sr} 56, \mathrm{Sr} 57$, and $\mathrm{Sr} 58)$ for APR to Ug99 have been described in wheat. These genes have been mapped to chromosomes 3BS, 4DL, 5BL, 7DS, and 1BL, respectively (Bansal et al. 2014; Herrera-Foessel et al. 2014; Lagudah et al. 2009; McFadden 1930; Singh et al. 2011b). One QTL on chromosome arm 6AS for APR to Ug99 has been reported in an association mapping study. This QTL was detected by two DArT (Diversity Arrays Technology) markers and located on the distal part of chromosome 6AS $(\mathrm{Yu}$ et al. 2011). In addition, both major gene alleles reported on 6AS ( $S r 8 a$ and $S r 8 b$ ) were ineffective against the Ug99 race group in Kenya (Jin et al. 2007). Therefore, the APR locus on chromosome 6AS of CItr 15026 is likely controlled by new genes or novel alleles of $\mathrm{Sr} 8$. Identification of APR to Ug99 is time consuming because plants must be grown to the heading stage in an environment where Ug99 is present, or a biosecurity facility where it is possible to inoculate with the Ug99 race group. Therefore, molecular markers tightly linked to the QTL region would be useful for wheat breeders to combine the APR locus from CItr 15026 with race-specific $S r$ genes. The SNP markers identified in the present study may facilitate rapid introgression of the new APR locus in CItr 15026 into wheat breeding lines using marker-assisted selection.

In conclusion, we described a source of APR to the Ug99 race group from wheat landrace accession CItr 15026. This APR should be useful in developing new wheat cultivars with durable stem rust resistance when deployed with major genes effective against Ug99. In addition, two complementary loci for seedling resistance to $P$. graminis $\mathrm{f}$. sp. tritici race TRTTF were identified from CItr 15026, and one of these loci conferred resistance to $P$. graminis f. sp. tritici races QFCSC and TTTTF.

\section{Acknowledgments}

We thank S. Stoxen and S. Gale for their technical assistance. This research was supported by the USDA-ARS National Plant Disease Recovery System, the USDA-ARS Current Research Information System project 2050-21000-02900D, and National Research Initiative Competitive Grant 2011-68002-30029 (Triticeae-CAP) from the USDA National Institute of Food and Agriculture.

\section{Literature Cited}

Babiker, E. M., Gordon, T. C., Chao, S., Newcomb, M., Rouse, M. N., Jin, Y., Wanyera, R., Acevedo, M., Brown-Guedira, G., Williamson, S., and Bonman, J. M. 2015. Mapping resistance to the Ug99 race group of the stem rust pathogen in a spring wheat landrace. Theor. Appl. Genet. 128:605-612.

Bajgain, P., Rouse, M. N., Bulli, P., Bhavani, S., Gordon, T., Wanyera, R., Njau, P., Leggesse, W., Anderson, J. A., and Pumphrey, M. O. 2015. Association mapping of North American spring wheat breeding germplasm reveals loci conferring resistance to Ug99 and other African stem rust races. BMC Plant Biol. 15: 249.

Bansal, U., Bariana, H., Wong, D., Randhawa, M., Wicker, T., Hayden, M., and Keller, B. 2014. Molecular mapping of an adult plant stem rust resistance gene Sr56 in winter wheat cultivar Arina. Theor. Appl. Genet. 127:1441-1448.

Dyck, P. L., and Green, G. J. 1970. Genetics of stem rust resistance in the wheat cultivar Red Bobs. Can. J. Plant Sci. 50:229-232.

Gao, L., Kielsmeier-Cook, J., Bajgain, P., Zhang, X., Chao, S., Rouse, M. N., and Anderson, J. A. 2015. Development of genotyping by sequencing (GBS)- and array-derived SNP markers for stem rust resistance gene Sr42. Mol. Breed. 35: 207.

Ghazvini, H., Hiebert, C. W., Zegeye, T., Liu, S., Dilawari, M., Tsilo, T., Anderson, J. W., Rouse, M. N., Jin, Y., and Fetch, T. 2012. Inheritance of resistance to Ug99 stem rust in wheat cultivar Norin 40 and genetic mapping of Sr42. Theor. Appl. Genet. 125:817-824.

Guerrero-Chavez, R., Glover, K. D., Rouse, M. N., and Gonzalez-Hernandez, J. L. 2015. Mapping of two loci conferring resistance to wheat stem rust pathogen races TTKSK (Ug99) and TRTTF in the elite hard red spring wheat line SD4279. Mol. Breed. 35:8.

Herrera-Foessel, S. A., Singh, R. P., Lillemo, M., Huerta-Espino, J., Bhavani, S., Singh, S., Lan, C., Calvo-Salazar, V., and Lagudah, E. S. 2014. Lr67/Yr46 confers adult plant resistance to stem rust and powdery mildew in wheat. Theor. Appl. Genet. 127:781-789.

Hiebert, C. W., Fetch, T. G., Jr., Zegeye, T., Thomas, J. B., Somers, D. J., Humphreys, D. G., McCallum, B. D., Cloutier, S., Singh, D., and Knott, D. R. 2011. Genetics and mapping of seedling resistance to Ug99 stem rust in Canadian wheat cultivars 'Peace' and 'AC Cadillac'. Theor. Appl. Genet. 122:143-149.

Jin, Y., and Singh, R. P. 2006. Resistance in U.S. wheat to recent eastern African isolates of Puccinia graminis f. sp. tritici with virulence to resistance gene $\mathrm{Sr} 31$. Plant Dis. 90:476-480.

Jin, Y., Singh, R. P., Ward, R. W., Wanyera, R., Kinyau, M., Njau, P., Fetch, T., Pretorius, Z. A., and Yahyaoui, A. 2007. Characterization of seedling infection types and adult plant infection responses of monogenic $\mathrm{Sr}$ gene lines to race TTKS of Puccinia graminis f. sp. tritici. Plant Dis. 91:1096-1099.

Jin, Y., Szabo, L. J., Pretorius, Z. A., Singh, R. P., Ward, R., and Fetch, T., Jr. 2008. Detection of virulence to resistance gene $\mathrm{Sr} 24$ within race TTKS of Puccinia graminis f. sp. tritici. Plant Dis. 92:923-926.

Jin, Y., Szabo, L J.., Rouse, M. N., Fetch, T., Jr., Pretorius, Z. A., Wanyera, R., and Njau, P. 2009. Detection of virulence to resistance gene Sr36 within race TTKS lineage of Puccinia graminis f. sp. tritici. Plant Dis. 93:367-370.

Kassa, M. T., You, F. M., Fetch, T. G., Jr., Fobert, P., Sharpe, A., Pozniak, C. J., Menzies, J. G., Jordan, M. C., Humphreys, G., Zhu, T., Luo, M.-C., McCartney, C. A., and Hiebert, C. W. 2016. Genetic mapping of SrCad and SNP marker development for marker-assisted selection of $\mathrm{Ug} 99$ stem rust resistance in wheat. Theor. Appl. Genet. 129:1373-1382.

Knott, D. R. 1989. The Wheat Rusts: Breeding for Resistance. Springer-Verlag, Berlin.

Knott, D. R. 1990. Near-isogenic lines of wheat carrying genes for stem rust resistance. Crop Sci. 30:901-905.

Lagudah, E. S., Krattinger, S. G., Herrera-Foessel, S., Singh, R. P., Huerta-Espino, J., Spielmeyer, W., Brown-Guedira, G., Selter, L. L., and Keller, B. 2009. Genespecific markers for the wheat gene $\mathrm{Lr} 34 / \mathrm{Yr} 18 / \mathrm{Pm} 38$ which confers resistance to multiple fungal pathogens. Theor. Appl. Genet. 119:889-898.

McFadden, E. S. 1930. A successful transfer of emmer characters to vulgare wheat. J. Am. Soc. Agron. 22:1020-1034.

Newcomb, M., Acevedo, M., Bockelman, H. E., Brown-Guedira, G., Jackson, E. W., Jin, Y., Njau, P., Rouse, M. N., Singh, D., Wanyera, R., Goates, B. J., and Bonman, J. M. 2013. Field resistance to the Ug99 race group of the stem rust pathogen in spring wheat landraces. Plant Dis. 97:882-890.

Newcomb, M., Olivera, P. D., Rouse, M. N., Szabo, L. J., Johnson, J., Gale, S., Luster, D. G., Wanyera, R., Macharia, G., Bhavani, S., Hodson, D., Patpour, M., Hovmollar, M. S., Fetch, T. G., Jr., and Jin, Y. 2016. Kenyan isolates of Puccinia graminis f. sp. tritici from 2008 to 2014: Virulence to SrTmp in the Ug99 race group and implications for breeding programs. Phytopathology 106:729-736.

Olivera, P., Newcomb, M., Szabo, L., Rouse, M. N., Johnson, J., Gale, S., Luster, D. G., Hodson, D., Cox, J. D., Burgin, L., Hort, M., Gilligan, C. A., Patpour, M., Justesen, A. F., Hovmollar, M. S., Woldeab, G., Hailu, E., Hundie, B., Tadesse, K., Pumphrey, M., Singh, R. P., and Jin, Y. 2015. Phenotypic and genotypic characterization of race TKTTF of Puccinia graminis f. $\mathrm{sp}$. tritici that caused a wheat stem rust epidemic in southern Ethiopia in 2013-14. Phytopathology 105:917-928.

Olivera, P. D., Jin, Y., Rouse, M., Badebo, A., Fetch, T., Singh, R. P., and Yahyaoui, A. 2012. Races of Puccinia graminis f. sp. tritici with combined virulence to $\mathrm{Sr} 13$ and $\mathrm{Sr} 9 \mathrm{e}$ in a field stem rust screening nursery in Ethiopia. Plant Dis. 96:623-628. 
Peterson, R. F., Campbell, A. B., and Hannah, A. E. 1948. A diagrammatic scale for estimating rust intensity on leaves and stems of cereals. Can. J. Res. 26c:496-500. Roelfs, A. P., and Bushnell, W. R. 1985. The Cereal Rusts, Volume II. Diseases, Distribution, Epidemiology, and Control.Academic Press Inc., Orlando, FL.

Roelfs, A. P., Singh, R. P., and Saari, E. E. 1992. Diseases of Wheat: Concepts and Methods of Disease Management. CIMMYT, Mexico City, Mexico.

Rouse, M., Wanyera, R., Njau, P., and Jin, Y. 2011. Sources of resistance to stem rust race Ug99 in spring wheat germplasm. Plant Dis. 95:762-766.

Singh, R. P., Hodson, D. P., Huerta-Espino, J., Jin, Y., Bhavani, S., Njau, P., Herrera-Foessel, S. A., Singh, P. K., Singh, S., and Govindan, V. 2011a. The emergence of Ug99 races of the stem rust fungus is a threat to world wheat production. Annu. Rev. Phytopathol. 49:465-481.

Singh, R. P., Hodson, D. P., Huerta-Espino, J., Jin, Y., Herrera-Foessel, S. A., Wanyera, R., Herrera-Foessel, S. A., and Ward, R. W. 2008. Will stem rust destroy the world's wheat crop? Adv. Agron. 98:271-309.

Singh, R. P., Huerta-Espino, J., Bhavani, S., Herrera-Foessel, S., Singh, D., Singh, P. K., Velu, G., Mason, R. E., Jin, Y., Njau, P., and Crossa, J. 2011b. Race non-specific resistance to rust diseases in CIMMYT spring wheats. Euphytica 179:175-186.

Singh, R. P., and McIntosh, R. A. 1987. Genetics of resistance to Puccinia graminis tritici in 'Chris' and 'W3746' wheats. Theor. Appl. Genet. 73:846-855.
Stakman, E. C., Stewart, D. M., and Loegering, W. Q. 1962. Identification of physiologic races of Puccinia graminis var. tritici. U. S. Dep. Agric. Agric. Res. Serv. E-617, Washington, DC.

Sthapit, J., Newcomb, M., Bonman, J. M., Chen, X., and See, D. R. 2014. Genetic diversity for stripe rust resistance in wheat landraces and identification of accessions with resistance to stem rust and stripe rust. Crop Sci. 54:2131-2139.

Wang, S. D., Wong, D., Forrest, K., Allen, A., Chao, S., Huang, E., Maccaferri, M. Salvi, S., Milner, S., Cattievelli, L., Mastrangelo, A. M., Whan, A., Stephen, S., Barker, G., Wieseke, R., Plieske, J., International Wheat Genome Sequencing Consortium, Lillemo, M., Mather, D., Apples, R., Dolferus, R., BrownGuedira, G., Korol, A., Akhunova, A. R., Feuillet, C., Salse, J., Morgante, M. Pozniak, C., Luo, M.-C., Dvorak, J., Morell, M., Dubcovsky, J., Ganal, M. Tuberosa, R., Lawley, C., Mikoulitch, I., Cavanagh, C., Edwards, K. J., Hayden, M., and Akhunov, E. 2014. Characterization of polyploid whea genomic diversity using a high-density 90000 single nucleotide polymorphism array. Plant Biotechnol. J. 12:787-796.

Yu, L.-X., Lorenz, A., Rutkoski, J., Singh, R. P., Bhavani, S., Huerta-Espino, J., and Sorrells, M. E. 2011. Association mapping and gene-gene interaction for stem rust resistance in CIMMYT spring wheat germplasm. Theor. Appl. Genet. 123:1257-1268. 